\title{
Performance of dairy cows fed silage and grain produced from second-generation insect-protected (Bacillus thuringiensis) corn (MON 89034), compared with parental line corn or reference corn
}

\author{
E. Castillo-Lopez, ${ }^{*}$ K. J. Clark, ${ }^{*}$ H. A. Paz, ${ }^{*}$ H. A. Ramirez Ramirez, ${ }^{*}$ T. H. Klusmeyer, $†$ G. F. Hartnell, $†$ \\ and P. J. Kononoff*1 \\ *Department of Animal Science, University of Nebraska-Lincoln, Lincoln 68583-0908 \\ †Monsanto Company, St. Louis, MO 63167
}

\section{ABSTRACT}

Corn grain and corn silage are major feed components in lactating dairy cow rations. Bacillus thuringiensis (B.t.) is a naturally occurring soil bacterium that produces a protein that is toxic to lepidopteran insects that may damage plant tissues and reduce corn quality and yields. During each of the four 28 -d periods, cows were offered 1 of 4 rations in which the corn grain and silage originated from different corn hybrids: a nontransgenic corn control (from hybrid DKC63-78; Monsanto Co., St. Louis, MO), a B.t. test substance corn (MON 89034 in hybrid DKC63-78; Monsanto Co.), and 2 commercial nontransgenic reference (Ref) hybrids: DKC61-42 (Ref 1) and DKC62-30 (Ref 2; Monsanto Co.). Sixteen multiparous Holstein cows averaging $110 \pm 21 \mathrm{~d}$ in milk and weighing $684 \pm 62.3 \mathrm{~kg}$ were blocked by days in milk and milk yield and randomly assigned to one of four $4 \times 4$ Latin squares. Diets were formulated to contain $36.4 \%$ corn silage and $16.3 \%$ corn grain. Dry matter intake was greater for cows consuming B.t. corn $(26.6 \pm 0.59 \mathrm{~kg} / \mathrm{d})$ compared with the control, Ref 1, and Ref 2 corn diets $(25.4,25.0$, and 25.6 $\pm 0.59 \mathrm{~kg} / \mathrm{d}$, respectively). Milk yield, fat yield, and percentage of fat $(36.8 \pm 0.98 \mathrm{~kg} / \mathrm{d}, 1.22 \pm 0.05 \mathrm{~kg} / \mathrm{d}$, and $3.3 \pm 0.10 \%)$, milk protein yield and percentage of protein $(1.11 \pm 0.03 \mathrm{~kg} / \mathrm{d}$ and $3.01 \pm 0.05 \%)$, milk urea nitrogen concentration $(14.01 \pm 0.49 \mathrm{mg} / \mathrm{dL})$, and $3.5 \%$ fat-corrected milk yield $(35.7 \pm 1.07 \mathrm{~kg} / \mathrm{d})$ were not different across treatments. The results from this study show that lactating dairy cows that consume B.t. corn (MON 89034) do not differ from lactating dairy cows that consume nontransgenic corn in milk yield, $3.5 \%$ fat-corrected milk per unit of dry matter intake, or milk components.

Key words: corn, silage, genetically engineered corn, milk production

Received January 2, 2014.

Accepted March 2, 2014.

${ }^{1}$ Corresponding author: pkononoff $2 @ u n l . e d u$

\section{INTRODUCTION}

Corn grain and corn silage continue to be a major component in rations fed to ruminants in the United States (Klopfenstein et al., 2013). In 2013, it was estimated that 97.4 million acres of corn were planted in the United States. Additionally, it is estimated that $90 \%$ of the corn planted is genetically engineered, a $50 \%$ increase since 2003 (USDA-ERS, 2013). Genetically engineered crop varieties and hybrids are used because they possess insect resistant and herbicide-tolerant traits and several large-scale reviews (Snell et al., 2012; Ricroch, 2013) have outlined that when tested, they are nutritionally equivalent to their non-genetically modified counterparts and may be safely used as feed and food. Monsanto (Monsanto Co., St. Louis, MO) has developed MON 89034 as a second-generation insectprotection product to control above-ground lepidopteran insect pests (Center for Environmental Risk Assessment, 2013). Product MON 89034 produces Cry1A.105 and Cry2Ab2 proteins derived from Bacillus thuringiensis (B.t.) that are active against Ostrinia species such as European corn borer and Asian corn borer, Diatraea species such as Southwestern corn borer and sugarcane borer, and helps control fall armyworm and corn earworm. The modes of action of Cry1A.105 and Cry2Ab2 (Drury et al., 2008) are different, specifically in the way they bind to the lepidopteran midgut. The combination of the 2 proteins provides a much more effective insect resistance management tool than a single protein (Center for Environmental Risk Assessment, 2013).

Regulatory agencies in the United States and around the world have approved MON 89034 corn for use as food and feed and concluded that MON 89034 corn is not materially different; however, the performance of lactating dairy cattle consuming MON 89034 corn has not been measured. Studies have been conducted with other biotech events in corn such as Bt 176 (Barrière et al., 2001), DAS-59122-7 (Brouk et al., 2011), MON 810 (Donkin et al., 2003; Calsamiglia et al., 2007; Steinke et al., 2009; Guertler et al., 2010), and Cry 1F (Faust et al., 2007), with no significant differences in milk yield 
and composition between test and control. Therefore, the objective of this study was to evaluate the effects of MON 89034 on feed intake, milk production, and milk composition.

\section{MATERIALS AND METHODS}

\section{Corn Silage and Grain}

Four corn hybrids, a test substance corn (B.t.; MON 89034 in hybrid DKC63-78; Monsanto Co.), a nontransgenic control (from hybrid DKC63-78; Monsanto Co.), and 2 commercial reference hybrids [DKC61-42 (Ref 1) and DKC62-30 (Ref 2); Monsanto Co.) were planted during the spring of 2009 at the University of Nebraska-Lincoln Agricultural Research and Development Center located near Mead, Nebraska. One plot of each hybrid was harvested on the same day for silage using a self-propelled John Deere forage harvester (Deere \& Co., Moline, IL). Approximately $100 \mathrm{t}$ of each hybrid was placed in a bag silo (Ag-Bag International Ltd., Warrenton, OR) and ensiled for approximately 180 d. Grain was harvested at physiological maturity from the remaining corn in the field plot. Table 1 contains the chemical composition of the corn silage and Table 2 contains the chemical composition of the corn grain used in the experimental diets. Ground corn was stored in steel overhead grain bins at the University of Nebraska-Lincoln feed mill before inclusion in the grain mix, which included all feeds except the forages, cottonseed, and the wet corn gluten feed. This mix was then transported to the dairy research unit where it was stored in a commodity shed. Samples of all hybrids were collected and sent to Monsanto Co. where the presence or absence of the cry1A.105 and cry2Ab2 genes was verified by event-specific PCR analyses (Dinon et al., 2011). Approximately $2 \mathrm{wk}$ before formulating rations for the experiments, corn silage was subsampled from the Ag-Bag by randomly opening each bag in 6 locations along the total length of the bag, comingling, and taking a random grab sample. These subsamples along with corn grain were sent to Dairy One Forage Laboratory (Ithaca, NY) for nutrient analysis.

\section{Experimental Design and Treatment Assignments}

Sixteen lactating multiparous Holstein cows averaging $110 \pm 21$ (mean \pm SD) DIM and weighing $684 \pm 62$ $\mathrm{kg}$ were randomly assigned to one of four $4 \times 4$ Latin squares (each square contained a different assignment of treatments). Cows were blocked by DIM and milk yield and then randomly assigned to balanced treatment sequences in each Latin square. During each of the four 28-d periods, cows were offered 1 of 4 TMR that differed by corn silage hybrid. Cows were identified by 2 ear tags and a transponder and observed daily. The animal

Table 1. Chemical composition of the 4 types of corn silage and forages used during the experiment $(\mathrm{n}=4)$

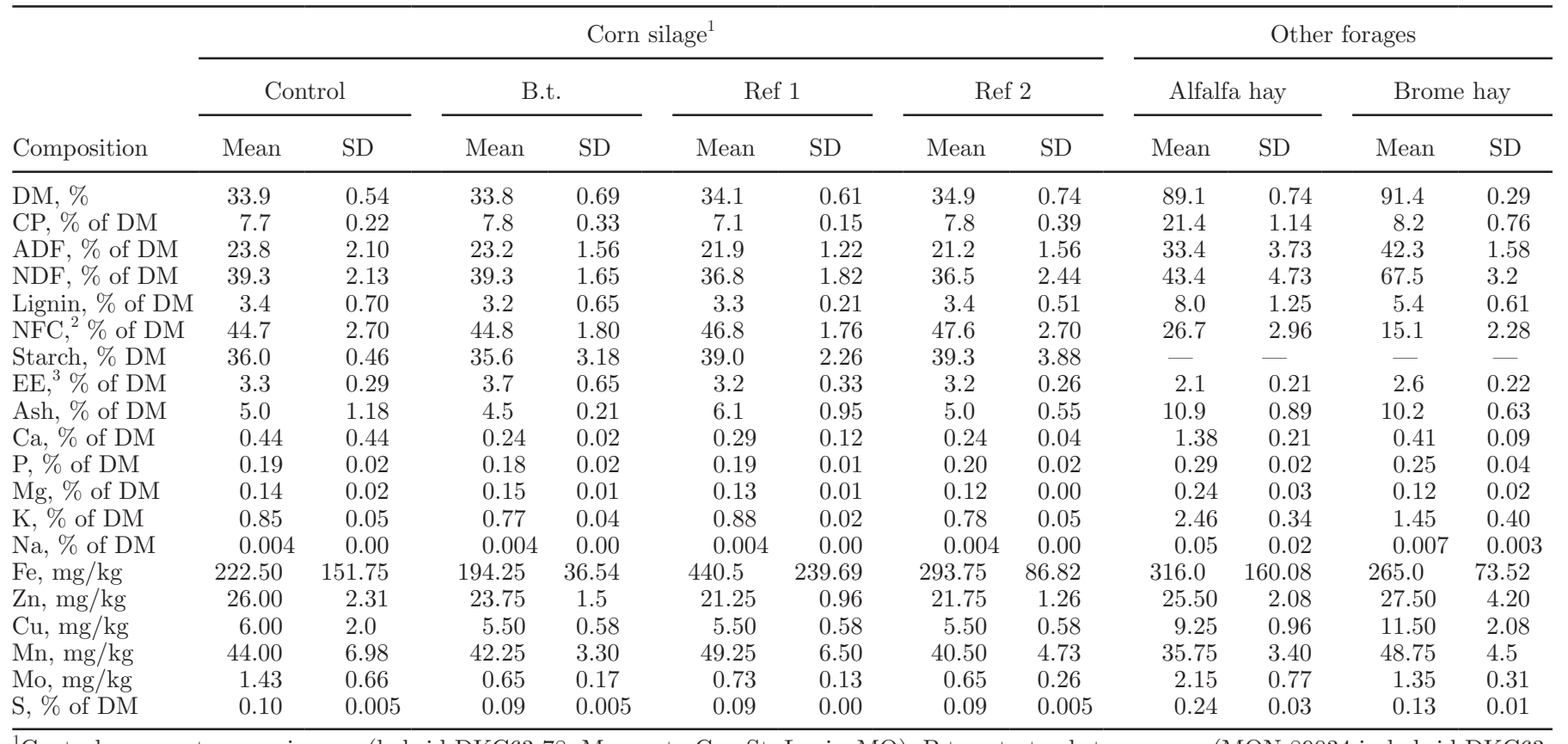

${ }^{1}$ Control = a nontransgenic corn (hybrid DKC63-78; Monsanto Co., St. Louis, MO); B.t. = test substance corn (MON 89034 in hybrid DKC6378; Monsanto Co.); Ref 1 and Ref $2=$ DKC61-42 and DKC62-30 (Monsanto Co.), respectively, which are 2 commercial reference (Ref) hybrids. ${ }^{2}$ Calculated by difference: $100-(\% \mathrm{NDF}+\% \mathrm{CP}+\%$ ether extract $+\%$ ash $)$.

${ }^{3}$ Ether extract. 
Table 2. Chemical composition of the corn grain (DM basis) used during the experiment $(\mathrm{n}=2)$

\begin{tabular}{|c|c|c|c|c|c|c|c|c|}
\hline \multirow[b]{3}{*}{ Composition } & \multicolumn{8}{|c|}{ Corn grain ${ }^{1}$} \\
\hline & \multicolumn{2}{|c|}{ Control } & \multicolumn{2}{|c|}{ B.t. } & \multicolumn{2}{|c|}{ Ref 1} & \multicolumn{2}{|c|}{ Ref 2} \\
\hline & Mean & $\mathrm{SD}$ & Mean & $\mathrm{SD}$ & Mean & $\mathrm{SD}$ & Mean & SD \\
\hline DM, \% & 85.5 & 1.20 & 85.8 & 3.68 & 90.1 & 0.84 & 89.8 & 0.35 \\
\hline $\mathrm{CP}, \%$ of $\mathrm{DM}$ & 9.3 & 0.21 & 9.5 & 0.14 & 8.3 & 0.14 & 9.2 & 0.14 \\
\hline $\mathrm{ADF}, \%$ of $\mathrm{DM}$ & 2.0 & 0.00 & 3.1 & 0.71 & 2.9 & 0.42 & 3.5 & 0.78 \\
\hline $\mathrm{NFC}^{2}, \%$ of $\mathrm{DM}$ & 77.8 & 1.77 & 76.5 & 1.77 & 79.1 & 0.14 & 76.9 & 0.28 \\
\hline Starch, \% of DM & 72.0 & 5.37 & 69.1 & 4.88 & 73.5 & 0.00 & 71.9 & 0.00 \\
\hline $\mathrm{EE},{ }^{3} \%$ of DM & 4.7 & 0.21 & 4.7 & 0.35 & 3.7 & 0.35 & 4.2 & 0.00 \\
\hline Ash, $\%$ of DM & 1.4 & 0.37 & 1.6 & 0.30 & 1.4 & 0.24 & 1.6 & 0.54 \\
\hline $\mathrm{Ca}, \%$ of $\mathrm{DM}$ & 0.03 & 0.02 & 0.03 & 0.02 & 0.03 & 0.02 & 0.06 & 0.007 \\
\hline $\mathrm{P}, \%$ of $\mathrm{DM}$ & 0.30 & 0.01 & 0.32 & 0.01 & 0.27 & 0.00 & 0.30 & 0.007 \\
\hline $\mathrm{Mg}, \%$ of $\mathrm{DM}$ & 0.11 & 0.00 & 0.11 & 0.00 & 0.12 & 0.00 & 0.11 & 0.00 \\
\hline $\mathrm{Mn}, \mathrm{mg} / \mathrm{kg}$ & 6.0 & 1.41 & 7.50 & 2.12 & 6.00 & 1.41 & 8.50 & 2.12 \\
\hline $\mathrm{Mo}, \mathrm{mg} / \mathrm{kg}$ & 0.45 & 0.07 & 0.35 & 0.07 & 0.34 & 0.07 & 0.60 & 0.00 \\
\hline S, \% of DM & 0.11 & 0.00 & 0.12 & 0.01 & 0.11 & 0.01 & 0.11 & 0.00 \\
\hline
\end{tabular}

${ }^{1}$ Control = a nontransgenic corn (hybrid DKC63-78; Monsanto Co., St. Louis, MO); B.t. = test substance corn (MON 89034 in hybrid DKC6378; Monsanto Co.); Ref 1 and Ref $2=$ DKC61-42 and DKC62-30 (Monsanto Co.), respectively, which are 2 commercial reference (Ref) hybrids. ${ }^{2}$ Calculated by difference: $100-(\% \mathrm{NDF}+\% \mathrm{CP}+\%$ ether extract $+\%$ ash $)$.

${ }^{3}$ Ether extract.

care staff were blinded to treatments. To do so, each hybrid was randomly assigned a letter before beginning the trial. This letter was used for all logistical practices associated with executing this study. Examples of such practices are labeling silage bags, noting rations on feed sheets, and identifying corn in grain mixes.

\section{Animal Care and Facilities}

Cows were housed at the University of Nebraska Dairy Research Unit (Mead, NE) and cared for according to guidelines by the University of Nebraska Institutional Animal Care and Use Committee. Cows were housed in individual stalls, milked daily at 0730 and $1930 \mathrm{~h}$, fed at $0900 \mathrm{~h}$ for ad libitum consumption to allow for approximately $10 \%$ refusals, and allowed water ad libitum. Feed intake and refusal were recorded daily throughout the study. Rations were formulated to meet or exceed the nutritional recommendations set forth in the current NRC (2001) guidelines. Diets had similar ingredient composition except for the source of corn silage and corn grain (Table 3 ).

\section{Feed Composition, Particle Size, BW, BCS, Milk Yield, and Milk Composition}

Total mixed rations were sampled 3 times during the last week of the treatment period, and compos- ited by treatment. The Penn State Particle Separator (The Pennsylvania State University, University Park) was used to measure the distribution of particle size of TMR according to Heinrichs and Kononoff (2002). Corn silage, alfalfa hay, brome hay, and grain samples were collected once during the last week of each period, dried for $48 \mathrm{~h}$ at $55^{\circ} \mathrm{C}$ in a forced-air oven, ground to pass through a 1-mm screen (Wiley mill; Arthur H. Thomas Co., Philadelphia, PA), and composited by sample for each period. Feed ingredients and TMR samples were sent to Dairy One Forage Laboratory for nutrient analysis. Collected feed ingredient and TMR samples were dried for $48 \mathrm{~h}$ at $60^{\circ} \mathrm{C}$ in a forced-air oven, ground to pass through a 1-mm screen (Wiley Mill; Arthur H. Thomas Co.), and analyzed for chemical composition, which included DM (method 930.15; AOAC International, 2000), ADF (method 989.03; AOAC International, 2000), N [method 990.03 (AOAC International, 2000); Leco FP-528 Nitrogen Combustion Analyzer (Leco Corp., St. Joseph, MI)], NDF (Van Soest et al., 1991), lignin (method 2003.05; AOAC International, 2000), ether extract using diethyl ether (method 2003.05; AOAC International, 2000), ash (method 942.05; AOAC International, 2000), and Ca, $\mathrm{P}, \mathrm{Mg}, \mathrm{K}, \mathrm{Na}, \mathrm{Fe}, \mathrm{Zn}, \mathrm{Cu}, \mathrm{Mn}, \mathrm{Mo}$, and $\mathrm{S}$ (Sirois et al., 1994). Starch was measured using a YSI 2700 SELECT Biochemistry Analyzer (YSI Inc. Life Sciences, Yellow Springs, OH). Corn silage samples were collected week- 
Table 3. Ingredient composition of the TMR fed during the experiment (DM basis)

\begin{tabular}{|c|c|c|c|c|}
\hline \multirow[b]{2}{*}{ Diet ingredient, $\%$} & \multicolumn{4}{|c|}{ Treatment $^{1}$} \\
\hline & Control & B.t. & Ref 1 & Ref 2 \\
\hline Corn silage DKC63-78 & 36.4 & - & - & - \\
\hline Corn silage MON 89034 & - & 36.4 & - & - \\
\hline Corn silage DKC61-42 & - & - & 36.4 & - \\
\hline Corn silage DKC62-20 & - & - & - & 36.4 \\
\hline Ground corn DKC63-78 & 16.3 & - & - & - \\
\hline Ground corn MON 89034 & - & 16.3 & - & - \\
\hline Ground corn DKC61-42 & - & - & 16.3 & - \\
\hline Ground corn DKC62-20 & - & - & - & 16.3 \\
\hline Wet corn gluten feed & 12.0 & 12.0 & 12.0 & 12.0 \\
\hline Alfalfa hay & 9.58 & 9.58 & 9.58 & 9.58 \\
\hline Soybean meal & 9.58 & 9.58 & 9.58 & 9.58 \\
\hline Brome hay & 2.88 & 2.88 & 2.88 & 2.88 \\
\hline Cottonseed & 8.24 & 8.24 & 8.24 & 8.24 \\
\hline Sodium bicarbonate & 0.65 & 0.65 & 0.65 & 0.65 \\
\hline Vitamin premix $^{2}$ & 0.12 & 0.12 & 0.12 & 0.12 \\
\hline Magnesium oxide & 0.29 & 0.29 & 0.29 & 0.29 \\
\hline Calcium carbonate & 1.73 & 1.73 & 1.73 & 1.73 \\
\hline Mineral premix ${ }^{3}$ & 0.12 & 0.12 & 0.12 & 0.12 \\
\hline SoyPass ${ }^{4}$ & 1.63 & 1.63 & 1.63 & 1.63 \\
\hline Salt & 0.38 & 0.38 & 0.38 & 0.38 \\
\hline Dicalcium phosphate & 0.10 & 0.10 & 0.10 & 0.10 \\
\hline \multicolumn{5}{|l|}{ Particle size } \\
\hline$>19.0 \mathrm{~mm}, \%$ & 15.1 & 13.7 & 18.1 & 14.9 \\
\hline $19.0-8.0 \mathrm{~mm}, \%$ & 31.6 & 32.2 & 26.7 & 28.8 \\
\hline $8.0-1.18 \mathrm{~mm}, \%$ & 40.7 & 41.4 & 40.4 & 42.3 \\
\hline$<1.18 \mathrm{~mm}, \%$ & 12.6 & 12.7 & 14.8 & 14.0 \\
\hline
\end{tabular}

${ }^{1}$ Control $=$ a nontransgenic corn (hybrid DKC63-78; Monsanto Co., St. Louis, MO); B.t. = test substance corn (MON 89034 in hybrid DKC63-78; Monsanto Co.); Ref 1 and Ref 2 = DKC61-42 and DKC62-30 (Monsanto Co.), respectively, which are 2 commercial reference (Ref) hybrids.

${ }^{2}$ Formulated to supply approximately $120,000 \mathrm{IU}$ of vitamin A/d, 24,000 IU of vitamin D/d, and $800 \mathrm{IU}$ of vitamin $\mathrm{E} / \mathrm{d}$ in the total ration.

${ }^{3}$ Formulated to contain $1.0 \% \mathrm{Ca}, 0.50 \% \mathrm{P}, 0.36 \% \mathrm{Mg}$, and $1.3 \% \mathrm{~K}$.

${ }^{4}$ LignoTech (Overland Park, KS).

${ }^{5}$ Determined using the Penn State Particle Separator (The Pennsylvania State University, University Park; $\mathrm{n}$ $=4)$.

ly and DM content was determined using a microwave oven and rations were adjusted to account for changes in DM content.

Body weight was measured on d 26 to 28 of each period and averaged within period. Body condition score (1 to 5 scale) was measured by 2 trained individuals on $\mathrm{d}$ 0 and then every $28 \mathrm{~d}$, and measurements at each time period were averaged. The scoring method used was similar to that of Wildman et al. (1982), but reported to the quarter point. Milk production was measured twice daily and milk samples were collected during the a.m. and p.m. milkings on d 26 to 28 and preserved using 2-bromo-2-nitropropane-1,3-diol. During the last week of each period, daily DMI and milk yields were averaged. Milk samples were sent to Heart of America DHIA (Manhattan, KS) for laboratory analysis of fat, true protein, and MUN using a ChemSpec 150 Analyzer (Bentley Instruments Inc., Chaska, MN); then, 3.5\% FCM yield was determined as follows: $\mathrm{FCM}=$ [milk fat $(\mathrm{kg} / \mathrm{d}) \times 16.218]+[$ milk yield $(\mathrm{kg} / \mathrm{d}) \times 0.4324]$.

\section{Statistical Analyses}

Performance data were analyzed as a replicated $4 \times$ 4 Latin square, with model effects for square, period within square, and treatment as fixed effects as well as cow within square as a random effect. The MIXED procedure of SAS (version 9.1; SAS Institute Inc., Cary, NC) was used to analyze all data. Square by treatment interaction was tested but was not significant and, therefore, it was excluded from the model. Significance for all models was declared at $P \leq 0.05$. Data were reported as least squares means and standard errors of the mean.

\section{RESULTS AND DISCUSSION}

Table 1 lists the composition of the forages fed during the experiment and Table 2 lists the chemical composition of the corn grains. The DM content across hybrids in the current study was within practical recommendations of 30 to $40 \%$ for ensiling in bag structures (Allen 
Table 4. Chemical composition of total mixed rations fed during the experiment $(n=4)$

\begin{tabular}{|c|c|c|c|c|c|c|c|c|}
\hline Composition, $\%$ of DM & \multicolumn{8}{|c|}{ Treatment $^{1}$} \\
\hline DM & 55.0 & 0.41 & 54.8 & 0.52 & 54.8 & 0.74 & 55.4 & 0.97 \\
\hline $\mathrm{CP}$ & 17.5 & 1.23 & 17.6 & 1.04 & 17.1 & 0.93 & 18.1 & 0.89 \\
\hline $\mathrm{NDF}$ & 41.0 & 2.64 & 39.2 & 2.10 & 37.4 & 2.61 & 37.3 & 0.77 \\
\hline NFC & 29.3 & 3.01 & 30.5 & 2.49 & 33.8 & 1.82 & 31.7 & 1.56 \\
\hline
\end{tabular}

${ }^{1}$ Control = a nontransgenic corn (hybrid DKC63-78; Monsanto Co., St. Louis, MO); B.t. = test substance corn (MON 89034 in hybrid DKC6378; Monsanto Co.); Ref 1 and Ref 2 = DKC61-42 and DKC62-30 (Monsanto Co.), respectively, which are 2 commercial reference (Ref) hybrids.

et al., 1995). As expected, the nutrient contents of these hybrids were also similar and consistent with previous research comparing the composition or forage and grain from MON 89034 to conventional corn (Drury et al., 2008). The ingredient composition of the experimental diets is listed in Table 3. All rations were not different in ingredient composition except for the source of test articles (Table 3) and were not different in nutrient composition (Table 4).

Recently, Hartnell (2010) reported that in 13 studies in which transgenic corn was fed to dairy cattle, only 1 reported statistically significant differences compared with nontransgenic corn. Specifically, Calsamiglia et al. (2007) reported that the percentages of milk protein, lactose, and SNF in milk were increased in cows fed transgenic corn but the reason for this was not apparent. The current study was designed to evaluate response in dairy cows consuming the MON 89034, which, to date, has not been evaluated in lactating dairy cattle. Observations for 1 cow consuming the control during period 4 were removed because her DMI was low (17.8 $\mathrm{kg}$ ) and deemed to be an outlier because it was less than the overall mean minus 2.5 standard deviations. The reason for this observation was not apparent. Dry matter intake was observed to be affected by hybrid $(P$ $=0.01$; Table 5). Specifically, DMI was highest for cows consuming MON 89034 compared with cows consuming other hybrids. The reason for this observation is not entirely clear, as the chemical composition of the TMR was very similar across treatments. However, the yields of actual milk and 3.5\% FCM were not affected $(P \geq$ 0.09; Table 5) across treatments. Composition of milk, namely fat, protein, and MUN, was not affected ( $P$ $\geq 0.16$ ) by hybrid. In addition, the yields of fat and protein were not different across treatments. The effect of hybrid on milk production efficiency, calculated

Table 5. Effects of feeding insect-protected (Bacillus thuringiensis, B.t.), control, and reference (Ref 1 and Ref 2) corn silages and corn grains on milk production and composition, BW, BCS, and feed conversion

\begin{tabular}{|c|c|c|c|c|c|c|}
\hline \multirow[b]{2}{*}{ Item } & \multicolumn{4}{|c|}{ Treatment $^{1}$} & \multirow[b]{2}{*}{$\mathrm{SEM}^{2}$} & \multirow[b]{2}{*}{$P$-value } \\
\hline & Control & B.t. & Ref 1 & Ref 2 & & \\
\hline DMI, $\mathrm{kg} / \mathrm{d}$ & $25.4^{\mathrm{a}}$ & $26.6^{\mathrm{b}}$ & $25.0^{\mathrm{a}}$ & $25.6^{\mathrm{a}}$ & 0.59 & 0.01 \\
\hline Milk yield, $\mathrm{kg} / \mathrm{d}$ & 36.4 & 38.2 & 36.5 & 36.1 & 0.98 & 0.09 \\
\hline $3.5 \%$ FCM yield,${ }^{3} \mathrm{~kg} / \mathrm{d}$ & 35.4 & 36.7 & 35.6 & 34.9 & 1.07 & 0.25 \\
\hline Fat, \% & 3.34 & 3.29 & 3.37 & 3.31 & 0.10 & 0.66 \\
\hline Fat yield, $\mathrm{kg} / \mathrm{d}$ & 1.21 & 1.25 & 1.22 & 1.19 & 0.05 & 0.49 \\
\hline Protein, \% & 2.98 & 3.01 & 3.04 & 3.02 & 0.05 & 0.28 \\
\hline Protein yield, $\mathrm{kg} / \mathrm{d}$ & 1.08 & 1.14 & 1.11 & 1.09 & 0.03 & 0.11 \\
\hline MUN, mg/dL & 14.2 & 14.3 & 13.6 & 14.0 & 0.49 & 0.16 \\
\hline $\mathrm{FCM} / \mathrm{DMI}^{4}$ & 1.42 & 1.36 & 1.37 & 1.38 & 0.038 & 0.41 \\
\hline $\mathrm{BW}, \mathrm{kg}$ & 697.8 & 695.0 & 692.9 & 686.3 & 16.01 & 0.56 \\
\hline $\mathrm{BCS}^{5}$ & 3.20 & 3.20 & 3.18 & 3.19 & 0.08 & 0.94 \\
\hline
\end{tabular}

${ }^{1}$ Control $=$ a nontransgenic corn (hybrid DKC63-78; Monsanto Co., St. Louis, MO); B.t. = test substance corn (MON 89034 in hybrid DKC63-78; Monsanto Co.); Ref 1 and Ref 2 = DKC61-42 and DKC62-30 (Monsanto Co.), respectively, which are 2 commercial reference (Ref) hybrids.

${ }^{2}$ Highest SE of treatment means is shown.

${ }^{3} 3.5 \%$ FCM yield $=[$ milk fat $(\mathrm{kg} / \mathrm{d}) \times 16.218]+[$ milk yield $(\mathrm{kg} / \mathrm{d}) \times 0.4324]$.

${ }^{4} \mathrm{FCM} / \mathrm{DMI}=$ yield of $3.5 \% \mathrm{FCM}(\mathrm{kg}) / \mathrm{DMI}(\mathrm{kg} / \mathrm{d})$.

${ }^{5}$ Body condition score on a 1 to 5 scale according to Wildman et al. (1982). 
as FCM production per unit of DMI, was also tested and did not differ $(P=0.41)$ across treatments. Body weight and BCS were not different $(P \geq 0.56)$ across treatments. Although similar studies evaluating the effects of transgenic corn (DAS-59122-7) on dairy production have been recently published (Brouk et al., 2011); to our knowledge, no other dairy production research has been conducted on MON 89034; however, several studies have evaluated the effect of MON 810 (Donkin et al., 2003; Calsamiglia et al., 2007; Steinke et al., 2009). Of those studies, none have observed significant differences in DMI or milk production or composition compared with controls.

The results of this study demonstrate that lactating dairy cow milk performance is not different between cows fed MON 89034 and those fed nontransgenic corn. Additionally, no adverse health effects were observed throughout the study. Although the current study may lack scientific novelty, such observations are important because genetically engineered crops are a key technology used to meet the increasing global demands of feed and food (Van Eenennaam, 2013). Furthermore, results from this study are in agreement with those by other researchers (Barrière et al., 2001; Donkin et al., 2003; Calsamiglia et al., 2007; Faust et al., 2007; Steinke et al., 2009; Guertler et al., 2010; Brouk et al., 2011) who investigated the effects of other biotech traits in corn on dairy cattle performance.

\section{ACKNOWLEDGMENTS}

Financial support for this project was provided by Monsanto Company (St. Louis, MO).

\section{REFERENCES}

Allen, M., S. Ford, J. Harrison, C. Hunt, J. Lauer, R. Muck, G. Roth, S. Soderlund, and D. Undersander. 1995. Corn silage production, management, and feeding. North Central Regional (NCR) Publication 574. American Society of Agronomy (ASA), Madison, WI.

AOAC International. 2000. Official methods of analysis. 17th ed. AOAC International, Arlington, VA.

Barrière, Y., R. Vérité, P. Brunschwig, F. Surault, and J. C. Emile. 2001. Feeding value of silage maize estimated with sheep and dairy cows is not altered by genetic incorporation of Bt176 resistance to Ostrinia nubilalis. J. Dairy Sci. 84:1863-1871.

Brouk, M. J., B. Cvetkovic, D. W. Rice, B. L. Smith, M. A. Hinds, F. N. Owens, C. Iiams, and T. E. Sauber. 2011. Performance of lactating dairy cows fed corn as whole plants silage and grain produced from genetically modified corn containing event DAS59122-7 compared to a nontransgenic, near-isogenic control. J. Dairy Sci. 94:1961-1966.

Calsamiglia, S., B. Hernandez, G. F. Hartnell, and R. Phipps. 2007. Effects of corn silage derived from a genetically modified variety containing two transgenes on feed intake, milk production, and composition, and the absence of detectable transgenic deoxyribonucleic acid in milk in Holstein dairy cows. J. Dairy Sci. 90:4718-4723.
Center for Environmental Risk Assessment. 2013. GM crop database. Accessed Dec. 20, 2013. http://cera-gmc.org/uploads/Cry2Ab_ en.pdf.

Dinon, A. Z., T. W. Prins, J. P. van Dijk, A. C. M. Arisi, I. M. J. Scholtens, and E. J. Kok. 2011. Development and validation of real-time PCR screening methods for detection of cry1A.105 and cry2Ab2 genes in genetically modified organisms. Anal. Bioanal. Chem. 400:1433-1442.

Donkin, S. S., J. C. Velez, A. K. Totten, E. P. Stanisiewski, and G. F. Hartnell. 2003. Effects of feeding silage and grain from glyphosate-tolerant or insect-protected corn hybrids on feed intake, ruminal digestion, and milk production in dairy cattle. J. Dairy Sci. 86:1780-1788.

Drury, S. M., T. L. Reynolds, W. P. Ridley, N. Bogdanova, S. Riordan, M. A. Nemeth, R. Sorbet, W. A. Trujillo, and M. L. Breeze. 2008. Composition of forage and grain from second-generation insectprotected corn MON 89034 is equivalent to that of conventional corn (Zea mays L.). J. Agric. Food Chem. 56:4623-4630.

Faust, M., B. Smith, D. Rice, F. Owens, M. Hinds, G. Dana, and P. Hunst. 2007. Performance of lactating dairy cows fed silage and grain from a maize hybrid with the cry $1 \mathrm{~F}$ trait versus its nonbiotech counterpart. J. Dairy Sci. 90:5706-5713.

Guertler, P., V. Paul, K. Steinke, S. Wiedemann, W. Preißinger, C. Albrecht, H. Spiekers, F. Schwarz, and H. H. D. Meyer. 2010. Long-term feeding of genetically modified corn (MON810) - Fate of $c r y 1 A b$ DNA and recombinant protein during the metabolism of the dairy cow. Livest. Sci. 131:250-259.

Hartnell, G. F. 2010. Feeding transgenic feedstuffs to cattle. Pages 68-78 in Proc. 21st Florida Ruminant Nutr. Symp., Gainesville, FL. University of Florida, Gainesville.

Heinrichs, A. J., and P. J. Kononoff. 2002. Evaluating particle size of forages and TMRs using the Penn State Particle Size Separator. Technical Bulletin of The Pennsylvania State University, College of Agriculture Science, Cooperative Extension. DAS 96-20. The Pennsylvania State University, University Park.

Klopfenstein, T. J., G. E. Erickson, and L. L. Berger. 2013. Maize is a critically important source of food, feed, energy, and forage in the USA. Field Crops Res. 153:5-11.

NRC. 2001. Nutrient Requirements of Dairy Cattle. 7th rev. ed. Natl. Acad. Sci., Washington, DC.

Ricroch, A. E. 2013. Assessment of GE food safety using '-omics' techniques and long-term animal feeding studies. New Biotechnol. 30:349-354

Sirois, P. K., M. J. Reuter, C. M. Laughlin, and P. J. Lockwood. 1994. A method for determining macro and micro elements in forages and feeds by inductively coupled plasma atomic emission spectrometry. Spectroscopist 3:6-9.

Snell, C., A. Bernheim, J.-B. Berge, M. Kuntz, G. Pascal, A. Paris, and A. E. Ricroch. 2012. Assessment of the health impact of GM plant diets in long-term and multigenerational animal feeding trials: A literature review. Food Chem. Toxicol. 50:1134-1148.

Steinke, K., V. Paul, P. Gurtler, W. Preibinger, S. Wiedemann, C. Albrecht, H. Spiekers, H. H. D. Meyer, and F. J. Schwarz. 2009. Effects of long-term feeding of genetically modified maize (Bt-maize, MON 810) on dairy cows. Book of Abstracts of the 60th Annu. Mtg. Eur. Assoc. Anim. Prod., Barcelona, Spain, 24-27 August 2009. Book of Abstracts No. 15:3.

USDA-ERS (USDS Economic Research Service). 2013. Adoption of genetically engineered crops in the U.S. Accessed Dec. 12, 2013. http://www.ers.usda.gov/data-products/adoption-of-geneticallyengineered-crops-in-the-us/documentation.aspx\#.Upyv6ydvDMc.

Van Eenennaam, A. L. 2013. GMOs in animal agriculture: Time to consider both costs and benefits in regulatory evaluations. J. Anim. Sci. Biotechnol. 37:1-14.

Van Soest, P. J., J. B. Robertson, and B. A. Lewis. 1991. Methods for dietary fiber, neutral detergent fiber, and nonstarch polysaccharides in relation to animal nutrition. J. Dairy Sci. 74:3583-3597.

Wildman, E. E., G. M. Jones, P. E. Wagner, H. F. Troutt Jr., and T. N. Lesch. 1982. A dairy cow body condition scoring system and its relationship to selected production characteristics. J. Dairy Sci. 65:495-501. 